\title{
Chronology of Terrestrial Den Use by Polar Bears in Western Hudson Bay as Indicated by Tree Growth Anomalies
}

\author{
PETER A. SCOTT ${ }^{1,2}$ and IAN STIRLING ${ }^{1,3}$
}

(Received 10 May 2000; accepted in revised form 11 October 2001)

\begin{abstract}
In a large polar bear denning area inland from the coast of western Hudson Bay south of Churchill, Manitoba, previous denning activity was determined by examining tree growth anomalies in the black spruce (Picea mariana) around and above den sites. A concentrated sample of dens was examined at each of three lakes, and 14 additional den sites were sampled individually on nine lakes and streams, for a total of 31 den sites. Trees sampled at these den sites ranged in age from 46 to 236 years $(n=83$, mean $=136, S E \pm 95.66)$. Some individual den sites dated back at least 200 years. Although some dens had been used for up to 29 years, most were used for only 12 years or less, presumably until melting permafrost caused their collapse. Half of the dens were reused two years after their initial use, but the probability of den reuse declined in subsequent years to about 0.25 after 10 years. During the 20th century, coincident with a reduction in hunting during 1920-53 and the subsequent abandonment of York Factory, there appears to have been an increase in den activity and an accompanying change in the pattern of denning activity. The rate of disturbance to the trees at dens correlated significantly to the number of polar bear hides traded at York Factory over the $1840-1935$ period $(\mathrm{r}=0.654 ; p<0.005)$. During $1850-$ 99, denning activity was greater at points more distant from the trading post at York Factory. In 1900-53, there was an overall increase in denning activity, which was greatest in denning areas nearer to York Factory $(\mathrm{r}=-0.872 ; p<0.01)$. In $1954-93$, the increase in denning activity continued, but varied with distance from the coast $(\mathrm{r}=-0.724 ; p<0.05)$. Markrecapture studies undertaken from 1970 to 2000 confirm that female polar bears in the western Hudson Bay population have a long-term fidelity to this specific area for maternity denning, and from this study it is evident that the population has used this denning area for several hundred years at least.
\end{abstract}

Key words: polar bears, denning, black spruce, disturbances, York Factory, Hudson Bay

RÉSUMÉ. Dans une vaste zone où sont établies des tanières d'ours polaires située en retrait de la côte de la baie d'Hudson occidentale au sud de Churchill (Manitoba), on a déterminé l'activité liée aux tanières en examinant les anomalies de croissance de l'épinette noire (Picea mariana) autour et au-dessus des sites de tanières. On a étudié un échantillon concentré de tanières à chacun de trois lacs, et 14 lieux de mise bas supplémentaires ont fait l'objet d'un échantillonnage individuel à neuf lacs et cours d'eau, pour un total de 31 lieux de mise bas. L'âge des arbres échantillonnés à ces endroits allait de 46 à 236 ans ( $\mathrm{n}=83$, moyenne $=136$, écart-type $\pm 95,66$ ). Quelques lieux de mise bas individuels remontaient à au moins 200 ans. Bien que certaines tanières aient été utilisées aussi longtemps que 29 ans, la plupart ne l'avaient été que pendant 12 ans ou moins, probablement jusqu'à ce que la fonte du pergélisol provoque leur effondrement. La moitié des tanières étaient réutilisées deux ans après leur occupation initiale, mais, par la suite, la probabilité de réutilisation diminuait à environ 0,25 après 10 ans. Au cours du $\mathrm{XX}^{\mathrm{e}}$ siècle, parallèlement à une réduction de la chasse qui dura de 1920 à 1953 et à l'abandon ultérieur de York Factory, il semble y avoir eu une augmentation de l'activité liée aux tanières, accompagnée d'un changement dans le régime de l'activité liée à la mise bas. Le taux de perturbation des arbres situés près des tanières était fortement corrélé au nombre de peaux d'ours polaires échangées à York Factory entre 1840 et $1935(\mathrm{r}=0,654 ; p<0,005)$. De 1850 à 1899 , l'activité liée à la mise bas était plus grande aux endroits plus éloignés du poste de traite de York Factory. De 1900 à 1953, il y a eu une augmentation générale de l'activité liée à la mise bas, plus marquée dans les zones de mise bas les plus proches de York Factory $(\mathrm{r}=-0,872 ; p<0,01)$. De 1954 à 1993, l'augmentation dans l'activité liée à la mise bas s'est poursuivie, tout en variant avec l'éloignement de la côte ( $\mathrm{r}=-0,724 ; p<0,05)$. Les études de marquage-recapture entreprises de 1970 à 2000 confirment que les ourses polaires de la population de la baie d'Hudson occidentale manifestent une fidélité à long terme à l'égard de cette zone spécifique pour y établir leur tanière de mise bas, et il est évident à partir de cette étude que la population utilise cette zone de mise bas depuis au moins plusieurs siècles.

Mots clés: ours polaires, établissement de tanière pour la mise bas, épinette noire, perturbations, York Factory, baie d'Hudson

Traduit pour la revue Arctic par Nésida Loyer.

\footnotetext{
${ }^{1}$ Department of Biological Sciences, University of Alberta, Edmonton, Alberta T6G 2E9, Canada

${ }^{2} 62$ Adams Court, Uxbridge, Ontario L9P 1G3, Canada; pascott@interhop.net

${ }^{3}$ Canadian Wildlife Service, 5320 - 122 Street, Edmonton, Alberta T6H 3S5, Canada

(C) The Arctic Institute of North America
} 


\section{INTRODUCTION}

Throughout most of their circumpolar range, polar bears (Ursus maritimus) have their maternity dens in snow, mainly on land but also on multiyear ice floes found along the edge of the polar basin (Harington, 1968; Uspenski and Kistchinski, 1972; Lentfer, 1975; Larsen, 1985; Stirling and Andriashek, 1992; Amstrup and Gardner, 1994). Mark-recapture and satellite tracking studies have shown that polar bears are distributed in several populations around the polar basin (IUCN Polar Bear Specialist Group, 1998). Within populations, individual adult female polar bears appear to show fidelity to denning areas, if not necessarily to specific den sites, over decades or longer (e.g., Ramsay and Stirling, 1990; Amstrup and Gardner, 1994). However, evidence of old dens in the same general area, which would further support the concept of den fidelity, is impossible to collect because maternity dens in snow leave no lasting trace after they melt. If polar bears are returning to general areas over extended periods, it is important to identify the maternity denning habitat, as this information could be vital for ensuring the protection of individual populations.

On the western side of Hudson Bay, near the southern limit of polar bear range, the annual ice-free period begins between late June and mid-July, leaving the polar bears to fast on adjacent land until freeze-up in about early to mid-November (Stirling et al., 1977, 1999). Pregnant female polar bears in the western Hudson Bay population spend the ice-free period on land in northeastern Manitoba. However, because embryo implantation occurs between mid-September and mid-October, and cubs are probably born between mid-November and midDecember (Derocher et al., 1992), the bears are unable to return to the ice and hunt again before parturition. Thus, pregnant females remain on shore for about eight months, during which time they give birth to cubs and nurse them up to about $10-12 \mathrm{~kg}$ of weight before they return to the sea ice to hunt seals the following March (Ramsay and Stirling, 1988). Fall conditions west of Hudson Bay, however, are unlike those in most of the bears' circumpolar range. Often there is not enough snowfall by the time the pregnant females are ready to give birth, or persistent wind and high temperatures prevent formation of compacted drifts like those used for maternity denning in northern populations. For example, during 1955-92, Churchill had more than $15 \mathrm{~cm}$ of snow accumulation by 30 November in only 11 of 37 years (Meteorological Service of Canada, 1995). Therefore, from late summer until at least late November or December, most pregnant females occupy earth dens that have been dug into perennially frozen peat banks common in the riparian habitat (Clark et al., 1997). It appears that females give birth to their cubs in these earth dens and then expand the dens into the overlying snowdrifts later in the winter (Jonkel et al., 1972; Ramsay and Stirling, 1990; Clark et al., 1997).
The use of earth dens by polar bears in the southern and western regions around Hudson Bay was first investigated by Doutt (1967) and Jonkel et al. (1972). Since the first report in the late 1700s (Hearne, 1795), hundreds if not thousands of dens have been observed in the frozen peat that is prominent to the south of Churchill (Clark et al., 1997). Clark et al. (1997) found that the dens built and used intermittently by males during the summer (pit dens) were different from the dens that were built and occupied by females for up to seven months (maternity dens or "deep dens"). In this paper, we use the term "dens" to refer to deep dens, as defined by Clark et al. (1997). Many of the den sites appear to have been used repeatedly, possibly over several decades or more, judging from the disruptions to the surrounding vegetation. In particular, we noted trees-mainly black spruce (Picea mariana) and occasionally larch (Larix laricina), around den entrances, on den roofs, or along collapsed dens-that were positioned at different angles from surrounding trees or appeared to have been damaged.

Tree rings and wood structure anomalies have been used to study the development of riparian features, such as slumping banks and mounding from ice-push, as well as ice scour and shoreline erosion associated with changes in water level (Stockton and Fritts, 1973; Dionne, 1979; Bégin and Payette, 1988, 1991; Lepage and Bégin, 1996). Similarly, studies of the timing of damage to long-lived subarctic trees inflicted by mammals, such as porcupines (Erithizon dorsatum) (Payette, 1987), snowshoe hare (Lepus americanus) (Sinclair et al., 1993) or migrating caribou (Rangifer tarandus) (Morneau and Payette, 1998), have also been useful for developing long-term chronologies of the activities of mammal populations. Using a similar approach, we examined annual growth rings and wood structure in krummholz black spruce situated adjacent to polar bear dens. Our first objective was to estimate the ages of individual dens and how often they might have been used by identifying and dating changes in orientation or structural damage in the trees that may have resulted from den excavation by polar bears. Our second objective was to see if the spatial pattern of terrestrial den use by polar bears was influenced by distance from the coast or by human activities.

\section{METHODS}

\section{Study Area}

The study area is on the western coast of Hudson Bay south of Churchill, Manitoba $\left(57^{\circ} 00^{\prime}-58^{\circ} 50^{\prime} \mathrm{N}, 92^{\circ} 40^{\prime}-\right.$ $94^{\circ} 00^{\prime} \mathrm{W}$ ) (Fig. 1). The entire area was submerged under the Tyrrell Sea at the end of the last ice age, approximately 7000 years ago (Dredge and Nixon, 1992). The emergent land forms a relatively featureless plain inclined to the southwest, where it reaches less than $100 \mathrm{~m}$ in elevation, underlain by continuous permafrost and poorly drained. 


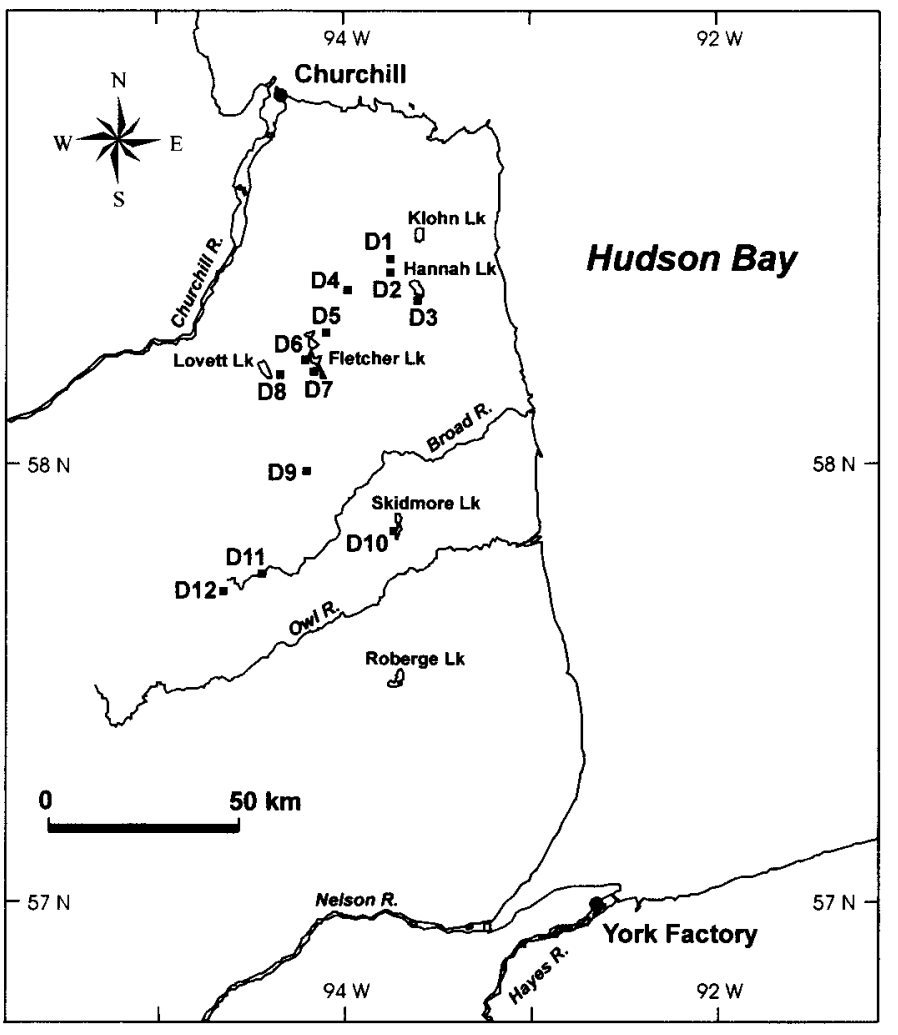

FIG. 1. Map of the denning area showing the three large lake sites (D3, Hannah; D7, Fletcher; D10, Skidmore) where aggregations of dens were studied and the nine other locations where isolated dens or small aggregations (1 to 3 dens) were found.

Because of ongoing emergence from Hudson Bay, the land farther inland from the present coast is older, and therefore, has had longer to accumulate fibric peat. The geobotany of the region, a transition zone between boreal forest and arctic tundra, is a mosaic of treeless expanses composed of polygonized peat bog (Ritchie, 1960, 1962). The bogs are interspersed with a high density of thermokarst ponds and shallow lakes (Dredge and Nixon, 1992) and braided streams outlined with riparian tree and shrub growth (Jonkel et al., 1972; Stirling et al., 1977; Ramsay and Stirling, 1990). Lichen-heath dominates in the drier sites and sphagnum dominates elsewhere.

Derocher and Stirling (1990) reported that lone (pregnant) females are, on average, found farther inland than other bears during the ice-free period. Details of the habitats used by these denning polar bears are given by Clark and Stirling (1997) and Clark et al. (1997). In general, the dens are common in the exposed peat banks, which can be up to $3 \mathrm{~m}$ in height. Woody tree species form a band along the water's edge that includes dwarf willows (Salix spp.) and birch (Betula glandulosa) in the lowest areas, with black spruce and occasionally tamarack on the upper slopes and level ground above. The black spruce krummholz is typically a clonal stand approximately 10 $15 \mathrm{~m}$ in width (see Payette and Delwaide, 1994; Payette et al., 1994). On the level ground above the bank the spruce stems were approximately $50 \mathrm{~cm}$ in height, while on the upper slope they occasionally exceeded $2 \mathrm{~m}$.

\section{Selection of Den Sites for Study}

We studied polar bear den sites during August and September from 1993 through 1996. A den site is a location that consists of a current den as well as all the earlier dens detected at that location. Two approaches were used to select sites for study. First, den sites were selected at Hannah, Skidmore, and Fletcher Lakes, which were known to have aggregations of dens and were located at increasing distances from the coast (about 20,36, and $53 \mathrm{~km}$, respectively; Fig. 1). We examined several den sites at each lake in order to enlarge the sample size without the expense of additional flying. This approach allowed us to test two hypotheses: a) that older areas have had more time to accumulate peat and to develop more stable plant communities and so have been used for a longer period of time, and $b$ ) that sites closer to the coast of Hudson Bay may have been used more often because bears require less energy to travel to them after coming ashore in summer. In the second approach, den sites were selected opportunistically while flying in a Bell 206B helicopter to search for polar bears as part of a long-term population study. These latter sites were found in isolation or in small aggregations (1-3 dens) at variable distances from both the coast and York Factory (Fig. 1). By selecting both occupied and unoccupied den sites in a nonrandom but nonselective manner, we could compare the isolated sites with those at the three lakes for additional insights they might provide. The sampling of sites spanning a wide north-south range made it possible to test the hypothesis that the human activity originating from the Hudson's Bay Company trading post at York Factory, near the southern boundary of the denning area, might have had a detectable influence on the pattern and frequency of terrestrial denning.

\section{Sampling Protocol}

To isolate the damage caused by polar bears excavating dens, we studied a subset of trees to identify the cause of damage and a tree's response, which could then be used to develop a sampling protocol for examination of more den sites. Wood samples were taken from heavily damaged areas of 22 black spruce krummholz at eight den sites and from four trees located near the dens but with no apparent damage (controls). Cross sections were taken at the centre of the damaged area and at $2-5 \mathrm{~cm}$ intervals on either side to determine which location would provide the best information. In all trees, a cross section was also taken near the root-stem base (the section of wood between the lowermost branches and the top of uppermost roots) to determine tree age and identify how localized stresses may be indicated in the stem and other parts of a tree. The root-stem base was located by repeatedly sectioning lower parts of the stem until the pith no longer existed.

Burial of lower stems causes wood developed subsequently to be more porous or root-like in character (Fayle, 


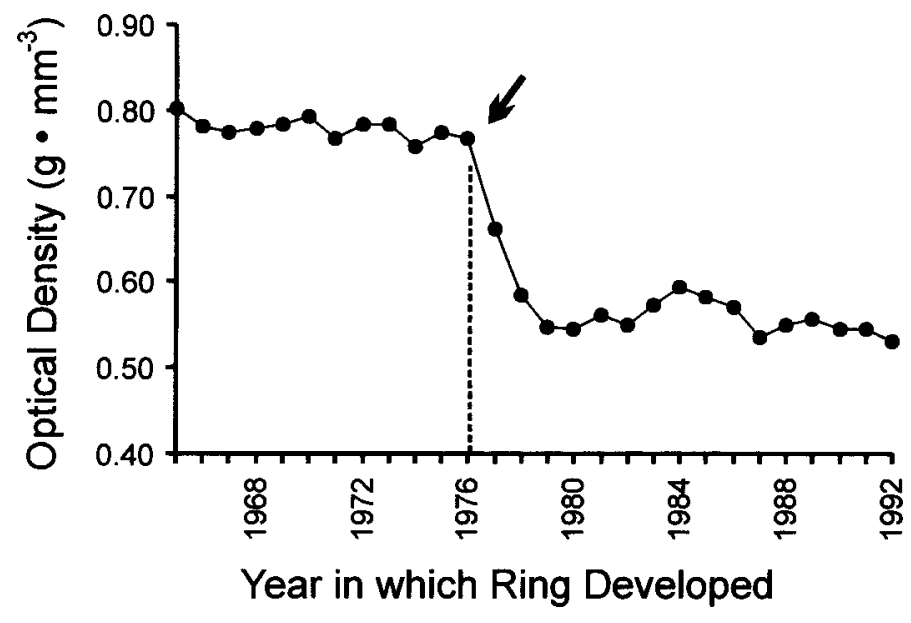

FIG. 2. Wood density in a stem cross section of a black spruce (1965-92) that was found covered with a large pile of loose peat. The stem experienced a reduction in the density of new wood during and after 1976 (arrow), and this new wood became more porous and root-like. The cell characteristics of the 1976 ring indicate that the pile of loose peat was deposited around the stem sometime in late August or early September 1976.

1968), and encourages black spruce to produce adventitious roots (Cournoyer and Filion, 1994). In peat, a tancoloured stain develops in the current and subsequent rings of buried stems (Cloutier, 1995). In the two samples where the spruce stems were buried in loose peat excavated from dens, examination of ring densities with DENDROSCAN (Varem-Sanders and Campbell, 1996) revealed an abrupt reduction in the wood density (Fig. 2) coincident with a tan staining (Fig. 3A).

The development of post-traumatic resin canals (TRC) is a characteristic of stressed or physically damaged wood (Panshin and de Zeeuw, 1970) and may be more pronounced in dwarf variants of a species (Jin-xing and Zheng-li, 1993). Close to the physical damage, the TRC were very dense and occurred in tangential lines completely around a ring. Farther away, the TRC were less dense and localized to the quadrant of the stem or root where the damage occurred (Fig. 3B). There were also TRC that appeared to be produced from severe bending and cracking of the tree stem, spring frost damage, and other unidentified stresses (e.g., Fig. 3C).

When a coniferous tree leans, reaction wood is produced on the lower side in association with wider rings that enable the tree to grow upright again (Wardrop, 1964). The patterns of reaction wood indicated that most undamaged trees located within the canopy were stressed by persistent onshore winds (Fig. 3D). For those spruce outstanding above the canopy, the prevailing winds from the northwest become a dominant stress. The wind effects were most pronounced in the stem at about 20 $50 \mathrm{~cm}$ above the ground (the trees were $50-200 \mathrm{~cm}$ high), while tree leans from shifting ground and bent stems were most pronounced close to ground level (Fig. 3E). Consequently, reaction wood in samples from ground level was used to detect ground shift and avoid bias from wind stress (Fig. 3F).
In the stems, branches, and roots from trees near the dens, we were able to identify characteristics that resulted from a variety of influences, including the year of stem burial or re-exposure, the occurrence of TRC that resulted from tree damage, ground shifts as indicated by reaction wood, and changes in ring-width patterns in response to localized disturbance. Minor damage to roots and branches in these dwarf spruce was so frequent that it was not possible to sort out all of the events that affected a tree. More extreme damage was manifest in sections of stem base; therefore, use of stem base samples served to filter "noise" created by an ambient level of minor damage to peripheral parts of the tree.

\section{Data Collection}

Samples of 17 den sites were investigated at three lakes, Skidmore (D10 - 4 sites), Fletcher (D7 - 7 sites), and Hannah (D3 - 6 sites). In addition, 14 individual sites were studied at nine other locations (Fig. 1), for an overall total of 31 den sites and 83 disturbed black spruce at 12 lake and stream site locations (Table 1). The location of each site was determined using a global positioning system (Garmin GPS 100, Lenexa, Kansas, U.S.A.). We measured the dimensions of each den within a site and mapped all chambers and tunnels, intact as well as collapsed. We also recorded the proximity to water, the height and orientation of the embankment and the den entrance, and the occurrence of excavated peat, as well as tree and shrub species present and composition of the peat above the glacialmarine sediments.

To identify bear damage, the following sampling protocol was used to isolate and eliminate the effects of localized weather, climate, and other riparian processes: 1) Well-developed trees that had little damage from secondary factors (i.e., damage from sources other than polar bears) were particularly scrutinized. 2) Trees that were low on the bank and thus prone to shoreline erosion and ice scour were avoided. 3) From one to five trees were selected from the roof, sides, or entranceway to a den, after which external damage to the spruce was identified and catalogued at the den sites (e.g., Fig. 3). The trees were sampled by sectioning near ground level and also at other locations that might provide more information about the cause of any particular stress. For example, a second section was taken at the peat-air interface of buried trees. 4) Local slumping of the bank, which occurs during ground thaw in late July and August, may also damage trees. To control for a possible bias resulting from such damage, a section from the root collar was also taken from the base of an undamaged spruce located along the bank approximately 3-5 $\mathrm{m}$ away from the den, and its ring width patterns were compared with those of nearby trees (Fig. 3D). 5) To isolate and control for large-scale weather and climate impacts, eight more trees were sampled several kilometres away from the dens, in more stable communities where denning did not occur. 


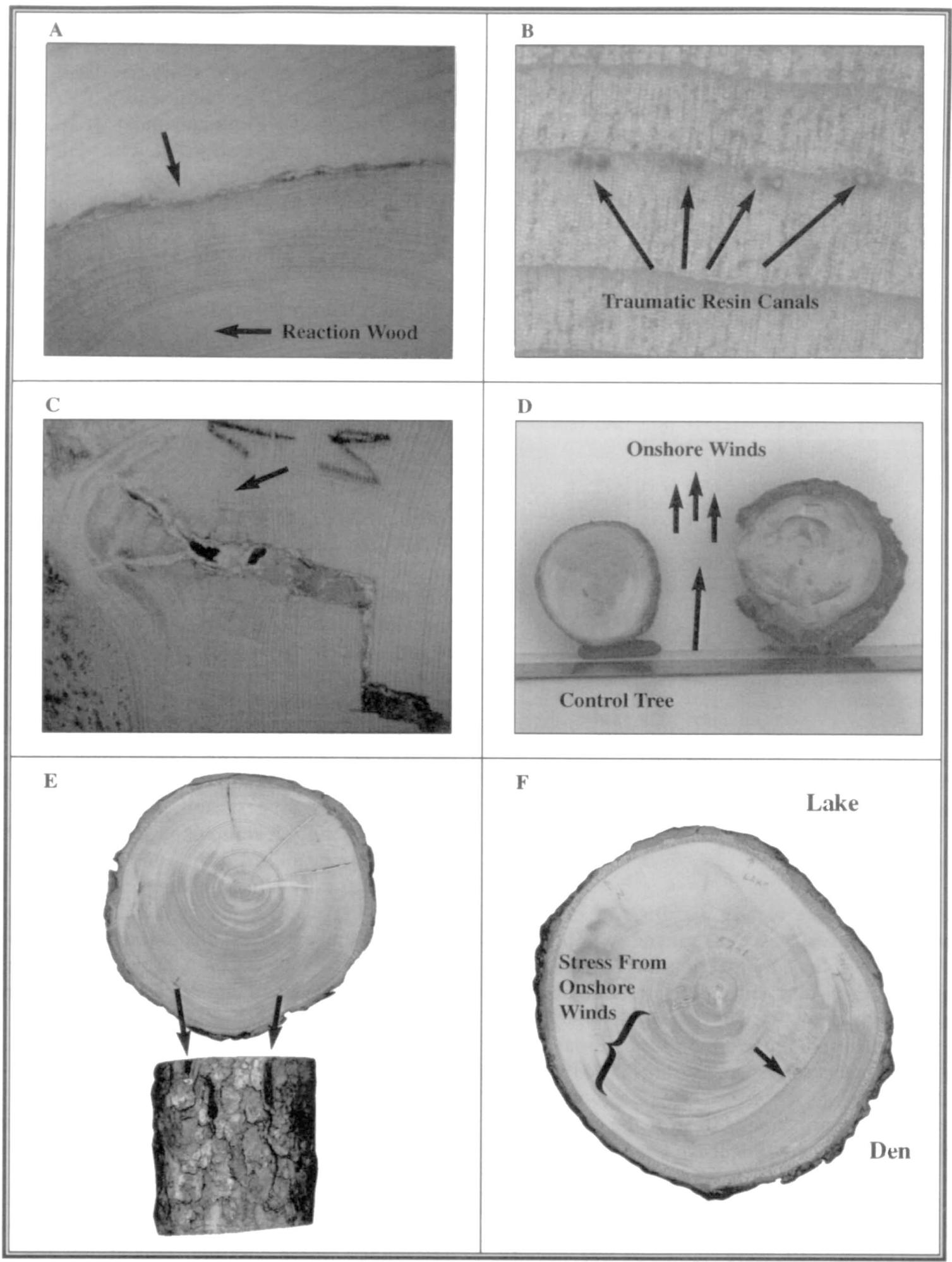

FIG. 3. Samples of black spruce stem cross sections. A) A lower stem with reaction wood indicating that it had been leaning for about 30 years when it was buried in peat (tan-coloured rings above reaction wood). The stem then lost its bark (upper arrow) and was "unburied," as indicated by a light yellow colouration and increased wood density in subsequent rings. B) Several Traumatic Resin Canals (TRC) near the outer edge of an annual ring (shown by arrows) suggest nearby trauma. The three rows of normal cells that developed after the trauma in this growing season indicate that the trauma occurred sometime during late August. C) A tree that cracked during an earlier dormant period (winter), from either heavy ice or snow load on the tree crown, has responded by producing the bulge at the left (arrow). D) A tree situated between the entrances to two dens (right cross section) has dark concentric lines in the wood, indicating it has been partially debarked repeatedly over the last century or more. Compare to a nearby control tree (left), which has reaction wood patterns typical of the trees stressed only by onshore winds. E) Localized damage to the wood during late August 1967 can be seen as apparent claw marks noted on the tree stem in 1995 (arrows). A change in the pattern of the reaction wood indicates that the foundation of the tree was shifted at the same time. F) A tree alongside a polar bear den originally had reaction wood typical of trees stressed by onshore winds. However, the location of the reaction wood changed (arrow) as the tree abruptly began to lean toward the polar bear den. The timing of the shift of the stem base indicates a major ground disturbance, which was likely caused by a polar bear constructing its den. 
TABLE 1 . The year of first ring ( $\pm 2 \mathrm{yr}$ ) for the 83 disturbed spruce sampled at 31 den sites representing 12 different locations (Fig. 1). ${ }^{1}$

\begin{tabular}{|c|c|c|c|}
\hline $\begin{array}{l}\text { Den Site } \\
\text { Location and } \\
\text { Designation }\end{array}$ & Den Site & $\begin{array}{l}\text { No. of Trees } \\
\text { (excluding } \\
\text { controls) }\end{array}$ & Year of First Ring \\
\hline \multirow[t]{2}{*}{ D1 } & U1 & 2 & 1809,1859 \\
\hline & $\mathrm{U} 2$ & 1 & 1840 \\
\hline D2 & BR1 & 3 & $1777,1892,1906$ \\
\hline \multirow[t]{6}{*}{ D3 (Hannah Lake) } & 25 & 5 & $1837,1907,1942,1943,1946$ \\
\hline & $25 \mathrm{G}$ & 3 & $1816,1877,1945$ \\
\hline & 26 & 4 & $1777,1807,1834,1834$ \\
\hline & 27 & 1 & 1818 \\
\hline & 29 & 2 & 1827,1876 \\
\hline & 30 & 5 & $1779,1794,1817,1827,1885$ \\
\hline D4 & ND1 & 5 & $1757,1796,1824,1854,1899$ \\
\hline \multirow{2}{*}{ D5 } & SD1 & 3 & $1808,1831,1866$ \\
\hline & SD2 & 2 & 1810,1888 \\
\hline D6 & CD2 & 2 & 1915,1919 \\
\hline \multirow[t]{7}{*}{ D7 (Fletcher Lake) } & F1 & 4 & $1771,1812,1880,1888$ \\
\hline & $\mathrm{F} 2$ & 2 & 1792,1878 \\
\hline & F4 & 2 & 1793,1868 \\
\hline & F5 & 3 & $1814,1842,1850$ \\
\hline & F6 & 3 & $1876,1884,1905$ \\
\hline & F7 & 3 & $1791,1840,1853$ \\
\hline & F8 & 1 & 1863 \\
\hline \multirow[t]{3}{*}{ D8 } & M3 & 2 & 1836,1872 \\
\hline & M4 & 1 & 1872 \\
\hline & M5 & 1 & 1896 \\
\hline D9 & BT1 & 3 & $1837,1879,1916$ \\
\hline \multirow[t]{4}{*}{ D10 (Skidmore Lake) } & ) $\mathrm{SK} 1$ & 3 & $1765,1837,1877$ \\
\hline & SK3 & 3 & $1802,1805,1850$ \\
\hline & SK4 & 3 & $1805,1844,1867$ \\
\hline & SK6 & 3 & $1934,1934,1940$ \\
\hline \multirow[t]{2}{*}{ D11 } & K1 & 3 & $1795,1818,1840$ \\
\hline & $\mathrm{K} 2$ & 3 & $1914,1914,1922$ \\
\hline D12 & $\mathrm{L} 1$ & 2 & 1938,1947 \\
\hline
\end{tabular}

${ }^{1}$ Ages from 46 to 236 years.

\section{Laboratory Analysis}

The tree sections were slowly air dried to minimize cracking, and the cut surfaces were sanded with progressively finer sandpaper. Each tree section was polished with 600 grit sandpaper and examined under a stereomicroscope using magnifications of $8-40 \times$. The ring widths were measured along radii corresponding to the four cardinal directions, using a tree ring increment measuring (TRIM) system (Fayle and MacIver, 1986), and then cross-dated with each other and with the control trees. Most of the stems were clonal, beginning as branches that leave a particular pattern of reaction wood related to snow load. Consequently, the oldest 20-50 rings of each stem were omitted from the analysis. The locations of TRC development within each ring were noted and the TRC were classed by size, density, and persistence throughout the ring. The presence and location of reaction wood and root-like wood were also noted. The localized damage to the roots, stems, and branches was also corroborated by stem traumas. A hierarchy of comparisons was undertaken, beginning with the four quadrants of each ring, the radii within each cross section, the cross sections for each den site collectively, each den site on a peat bank, and finally the denning area with other benchmark studies (Scott et al., 1988; Fayle et al., 1992).
More than 7000 disturbances resulting from many causes were identified in the samples. While physical recovery from the traumas may take years, the timing of the damage to a period within the growing season of each year enabled us to identify and eliminate most of the disturbances. Locally, TRC were associated with damage caused by windblown trees that brushed against each other (mostly in the fall before snow cover), caribou that rubbed their antlers along the stem (in the fall), stems and branches that broke during ice storms (in late fall), stems that cracked from severe freezing (mid-winter) or because of snow loaded on the crowns (May) (Fig. 3C), ice scour on the roots (mid-June to early July), ground that slumped because of thawing permafrost (August), and den excavation by polar bears (late July and August). It is known from other studies of spruce in the area (Scott et al., 1987, 1988; Fayle and Scott, 1995; Scott, unpubl. data) that annual stem development begins with apical bud swell during the last week of June and finishes at the base of the tree with lignification of the wood cells in the last week of August or the first week of September (late wood). During this period, the cambial cells enlarge in a sequence that begins with the cells closest to the ring of the previous year and progresses peripherally until, on average, between 16 and 24 rings of cells have developed. Damage to a tree will be manifested, either directly or as TRC and other reaction wood, within the particular row of cells that is developing at the time. Traumatic events for the trees that occur during the dormant period, between early September and the last week of June, are manifested in TRC at the start of the subsequent growing season. Because of the sigmoidal character of ring development, the first two-thirds of the ring will be produced during the time in July when the bears are usually absent. Consequently, only traumas to the trees that occurred during the month of August or very early September were considered. By comparing a tree with August damage to a nearby control tree, we could then eliminate growth anomalies relating to ground-thaw disturbances as well (Fig. 3D).

\section{Data Organization}

Within a den site, the moderate and heavy disturbances that occurred during August and early September for each tree were compared chronologically with other site trees to facilitate reconstruction of the timing of den establishment, frequency of use, and den collapse or rebuilding, as determined where possible. This allowed us to establish the minimum age of each den site, how often a den was occupied, and how often a new den was excavated at the original den site.

As den sites were often found in clusters along lake shores, the disturbance chronologies for individual den sites were grouped by location. The grouped chronologies for the three largest clusters of den sites (Hannah, Skidmore, and Fletcher Lake locations) were examined in relation to their distance from York Factory. To test the hypothesis 


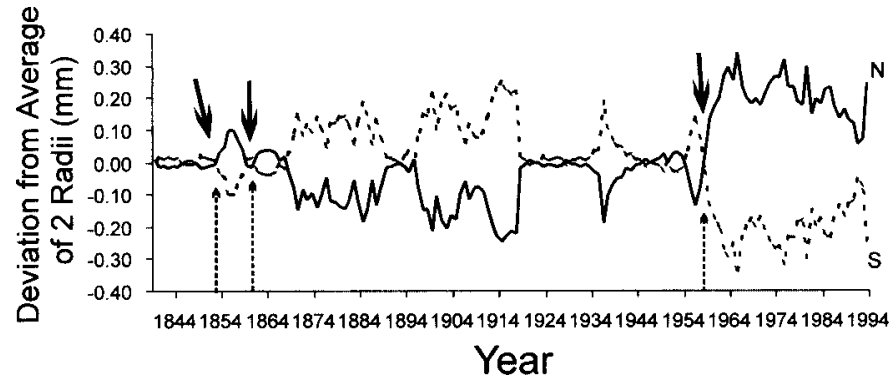

FIG. 4. A sample of north (solid line) and south (broken line) radii from a stem found at den F7 on Fletcher Lake. Stresses from the prevailing winds causing shifts to the south are evident here. Usually, the south rings are larger than those on the north. Three major shifts in the ground are shown by places where rings become larger on the north side of the tree (1853, 1861, 1959 arrows), indicating that the tree leaned toward the den.

that hunting and other human activities might have influenced denning activity, we examined the timing and frequency of den disturbances in relation to three time periods: (1) 1850-99, when polar bear hides were more or less traded consistently (Honderich, 1991); (2) 1900-53, when the number of hides traded became highly variable as progressive conservation measures were introduced and the human population at York Factory began to decline (Gleuk, 1957); and (3) 1954-93, the period during which the government of Manitoba banned commercial hunting of polar bears (Manitoba, 1954) and traditional hunters abandoned York Factory (Kidd, 1957). To control for possible human disturbances influencing annual den use, we analyzed den disturbance data from the post-hunting period (1954-93) in dens that had been vacant for at least 10 years.

The location of each grouped disturbance chronology was then correlated to the distance from the nearest coast to see if there were patterns that related to site selection either for energetic reasons or because of the age of the land (i.e., sufficient peat accumulations). A summary chronology of all dens was also calculated to examine den disturbance patterns over time and in relation to climate change and to hunting (as indicated by the number of polar bear hides traded annually at York Factory during 1840 1935). While polar bear hides were not a prime commodity, a relatively modest value was placed on trading them (Honderich, 1991), which no doubt encouraged hunting or at least the trading of hides for the record. At Severn Post on the coast to the southeast, three to four polar bear hides were traded annually and most, if not all, probably came from the southern Hudson Bay population. At Churchill, to the north of the denning area, from one to four hides were traded annually, and these were probably taken by Inuit hunters farther north, though most were likely harvested from the western Hudson Bay population. Most polar bear hides (20-50 annually) were traded at nearby York Factory and originated largely from hunting in our study area (Honderich, 1991).

Trade in polar bear hides at the Hudson's Bay Company post at York Factory through the entire period for which we were able to determine den disturbances has been documented by Honderich (1991). Consequently, we assembled a chronology of the number of hides traded at York Factory over time to compare with the rate of disturbance at the sampled dens for the period 1840-1935. (After 1935, the methods of fur reporting changed, as the responsibility came under the Dominion Bureau of Records [Keith, 1963]. Also, the development of the railway in the 1930s brought other traders into the region, eliminating the Hudson's Bay Company monopoly and the completeness of the trading records [Donaldson, 1981].) Because some of the hunting in any given year may have taken place after the annual ship had left York Factory and the Hudson's Bay Company fiscal year had ended, it was necessary to collate the stem and root data into two-year values prior to analysis.

\section{RESULTS}

\section{Samples of Tree Stems Collected}

With one exception, the ages of trees sampled on the banks around the dens ranged from 46 to 236 years (mean $=136, \mathrm{SE} \pm 95.66)$. One tree collected several kilometres from the nearest den as a control for larger-scale climatic variation was 383 yrs old. A Kolmogorov-Smirnov test of the frequency distribution (Sokal and Rohlf, 1995) indicated a normal distribution for ages of the disturbed trees. Consequently, we concluded that our collection of stems represented a nonselective sample of ages of trees present around the dens.

The dens were usually dug into embankments within or beneath black spruce that were forming a krummholz of cloned stems. In general, these spruce appeared clawed, debarked, broken, ripped out of the ground, buried under large piles of peat, or tilted at ground level, damage that likely occurred during excavation at the dens by polar bears. We identified 617 disturbances on 72 trees that occurred during the time of year when polar bears were denning in the area and which we were unable to attribute to any other source. The disturbances included debarking of large sections of the stem (Fig. 3D); abrupt leaning of the stem either into or away from the den, indicating a ground shift (Fig. 3F); burial of stems, or digging out of stems previously buried in peat (Fig. 3A); and internal damage to stems and roots from clawing (Fig. 3E), chewing, bending over, or other traumatic events that produced TRC (Fig. 3B). Almost all of the damage that was manifested in one way was corroborated by other types of reactions in the tree or in nearby trees as well (Fig. 4). By corroborating the timing of this type of damage at one den site with another damaged tree at the same site, we were able to consider these remaining disturbances to be caused by bears excavating or modifying a den. Unless moderate to heavy damage was indicated and could be corroborated with other trees, den activity could not be established with 


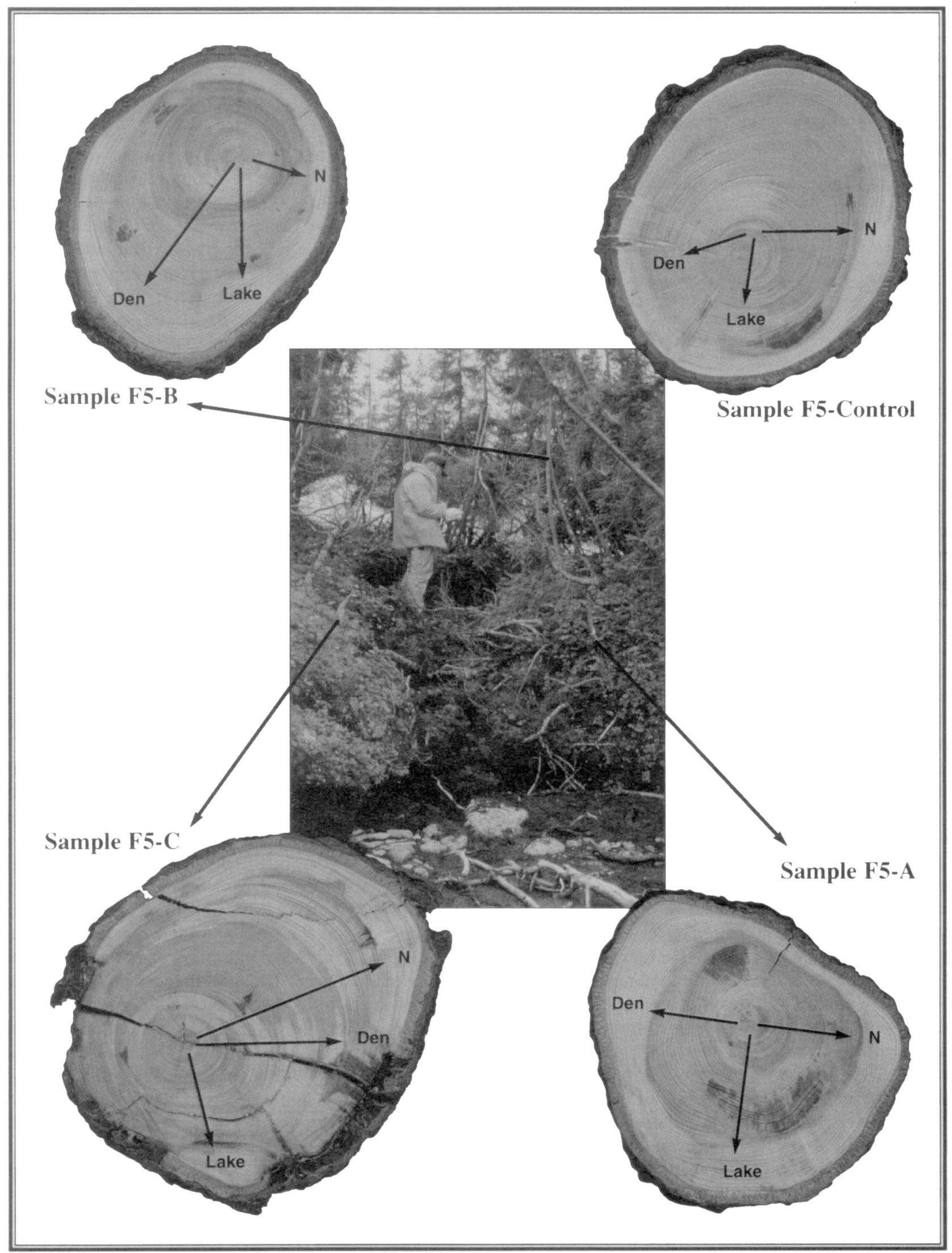

FIG. 5. Composite of an abandoned den (F5) on Fletcher Lake, showing the den, the locations of three black spruce sampled (arrows), and cross sections of their stem bases. Compared to the control tree (upper right), the three samples indicate ground shifts by unique changes in the patterns of reaction wood (dark colouring of wood) and ring widths, debarking (see 3A and 3D), and other physical damage inflicted during the denning season. The shoreline is at the entrance to the den in the bottom of the photo. 

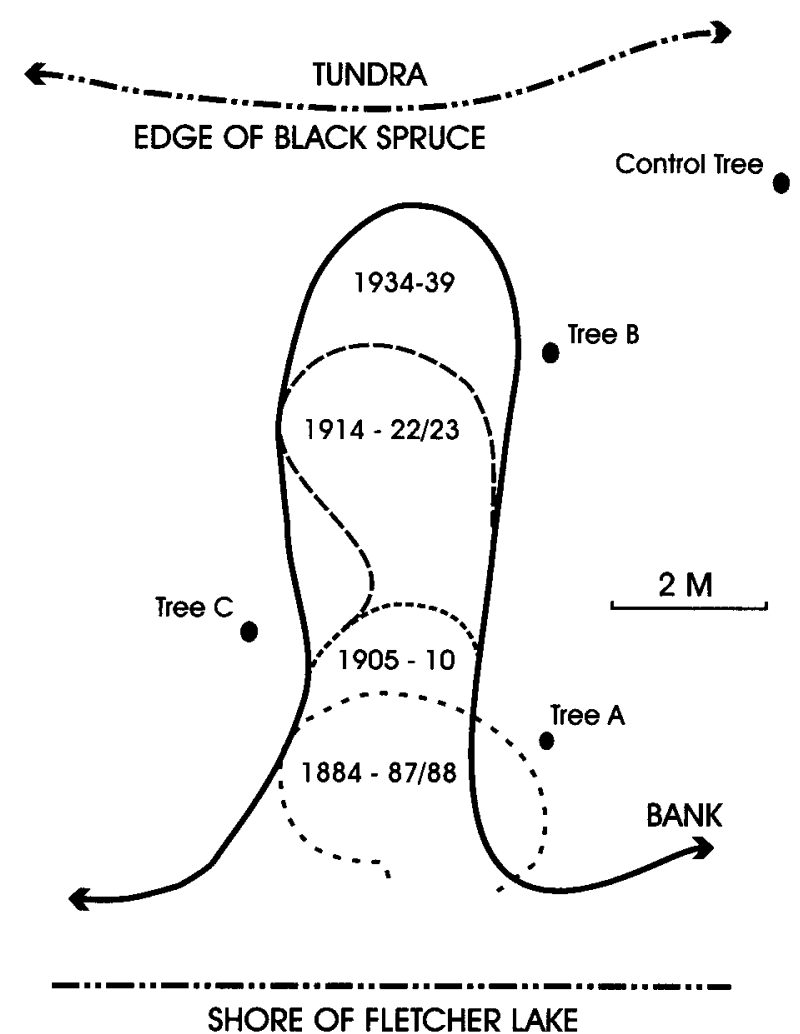

SHORE OF FLETCHER LAKE

FIG. 6. Plan view of our historical reconstruction of den F5 from Fletcher Lake (see Fig. 5 and text for detailed reconstruction).

certainty. Because we attempted to be conservative in our methods, we may have underestimated the damage caused by bears in our sample trees. The earliest such disturbance we identified dated from 1795, but $96 \%$ (592/617) of the disturbances that we attributed to polar bears occurred after the 1820 s.

\section{Chronology of Individual Den Use}

We used the timing and location of tree disturbances to interpret the history of den use at each site. In addition to ring and wood structure, we examined the vegetation that lines the old dens in many places (e.g., the bank below F5$\mathrm{C}$ in Fig. 5). These peat mats about $12-20 \mathrm{~cm}$ thick are, in fact, parts of the roof of earlier dens, which have collapsed into the hole. These relatively intact remnants have aided us in the historical reconstruction of the site as well as in dating the exposure of tree roots, such as those on the right bank in Figure 5. For example, we used the data established from disturbed trees at F5 to show our interpretation of the history of major excavation events in Figure 6. The pattern of ground shifts, as indicated by leaning in the study trees, suggests that the most shoreward den intact today was probably built parallel to the shore in 1884 and used at least in 1887 and 1888 as well. The first den entrance or roof collapsed, and a subsequent den was built

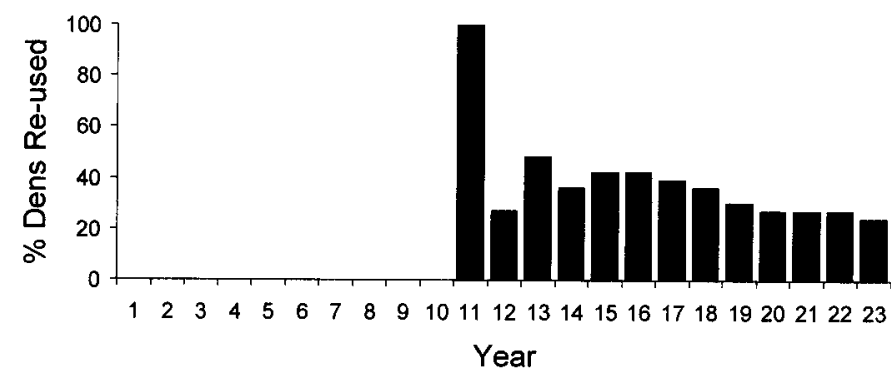

FIG. 7. A sample of den reuse for 38 dens that existed in the post-hunting period. For at least 10 years prior to reuse, there is no indication that the dens were disturbed. However, within two years after the first reuse, more than half of all dens were disturbed again, indicating that freshly used dens are of interest to polar bears.

farther inland in 1905 and used in 1910. In 1914, ground shifts indicate that a third den was built in behind the second den, but this time perpendicular to the shore. It appears to have been used during 1922-23. Again, behind the most recent den, a fourth den was excavated in 1934; but it did not last, as the trees around the dens are undisturbed after 1939. The first three dens were dug in woody peat and the last one was in sphagnum peat. Den sites appear to be abandoned when excavated as far inland as sphagnum, which is usually predominant on the inland side of the krummholz.

With a sample of 38 dens, we examined reuse during the post-hunting period (1954-93). Innumerable potential den sites are available, and only 150-200 females give birth each year (Derocher and Stirling, 1995; also derived from Stirling et al., 1999). Thus, we would not expect dens to be reused often if polar bears were selecting sites at random. We determined the percentage of the dens being used during each year from the frequency of disturbances for each sample site (Fig. 7). There were no disturbances detected at the den sites for each of the first 10 years before the current dens were reused. However, the first year after being reused, $28 \%$ of the dens were used again, and two years later, $48 \%$ of the dens were used. In subsequent years, the rate of reuse declined steadily, to $24 \% 12$ years after the first reuse. At least $57 \%$ of the dens had been used within two years after a den site was first re-occupied. These results may indicate an energetic saving, as a freshly maintained den probably requires little maintenance for a couple of years prior to ground thaw. Or perhaps bears are simply attracted to a recently used den.

\section{Chronology of Den Site Use}

Figure 8 summarizes the timing and rate of disturbance to trees at den sites on Hannah, Skidmore, and Fletcher Lakes beginning in 1840. Data from the more isolated den sites were included in the totals for all dens. We did not identify any possible pattern of den site disturbances until the early 1820 s, probably because the average age of trees sampled was only 136 years, so that the sample size for earlier periods was small. At Hannah Lake, the earliest den excavations dated from the late 1840s, and disturbances 

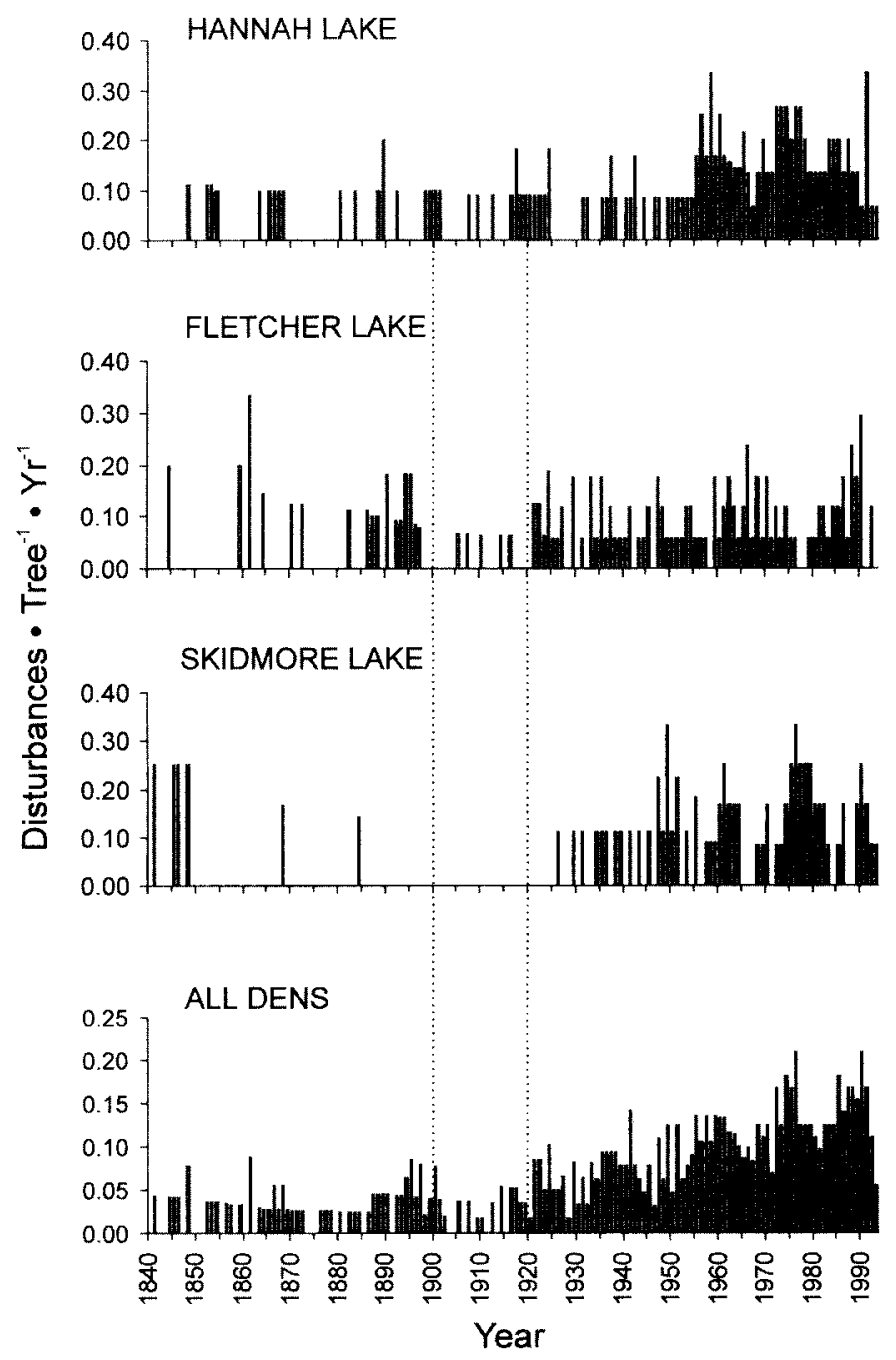

FIG. 8. The rates of disturbance per black spruce per year sampled at den sites on Hannah, Skidmore, and Fletcher Lakes, as well as for all dens sampled. The latter chronology has a different scale. The lack of disturbances before 1850 indicates that there was a smaller sample of trees, in part because thermokarst processes may have caused many of the banks to erode away. The vertical dotted lines delineate the period when polar bear hides traded at York Factory approximately doubled in number compared to 1840-99.

increased after 1954. At Skidmore Lake, the earliest excavation dated from the $1820 \mathrm{~s}$. After relatively heavy disturbance from 1820 to 1850 , a period of little use until the late 1920 s was followed by a higher level of use and disturbance in the 1950s. At Fletcher Lake, the earliest excavations date from the $1840 \mathrm{~s}$. The rate of disturbance was relatively consistent until it increased after the mid-1960s.

\section{Spatial Pattern of Den Site Use}

Of the dens around the seven lakes that were occupied during 1850-99, those at the two southernmost sites (D11 and Skidmore) had the lowest frequency of disturbance (0.020 and 0.060 respectively; see Fig. 9). During 1900 53 , the frequency of disturbance increased at all seven of those lakes (from 0.069 to 0.186 on average) and at three additional lakes, with the greatest increases in denning activity on lakes near York Factory (D11, 370\% and Skidmore, 660\%) and lesser increases at more distant lakes $(\mathrm{r}=-0.872 ; p<.01)$. During $1954-93$, the frequency of disturbance increased at 9 of those 10 lake sites (from 0.186 to 0.348 on average) and activity was recorded at an eleventh lake. However, there was a different trend, with the greatest increases in denning activity near the coast (Hannah, 347\% and D2, 323\%) and smaller increases on lakes farther inland $(\mathrm{r}=-0.724 ; p<.05)$. Although there is a trend towards a greater increase in disturbances in smaller lakes over time, correlation between the surface area of the lake and the frequency of disturbance was not statistically significant during any period.

\section{Chronology of Use of the Denning Area}

When data from all dens were pooled, we found a slight decline in the rate of disturbance to the trees through the 19 th century, an abrupt decline in the early 20th century, followed by an increase in the overall frequency of den disturbance after that (Fig. 8). For example, although the rate of disturbance per year per tree was 0.070 during the period 1820-40, disturbances occurred in only five years out of 20. By comparison, the rate of disturbance declined to 0.044 from 1880 through 1900 and disturbances were recorded in 18 years out of 20 . The period of lowest activity occurred during 1900-20 (0.039 disturbances per year per tree). This was followed by an erratic pattern of increases over the next 50 years, culminating in the highest recorded level of disturbance to trees adjacent to dens after 1970, when, on average, the frequency of disturbance was five times what it had been during the $1800 \mathrm{~s}$ ( 0.028 for $1850-99$ versus 0.140 for $1970-89$ ).

\section{DISCUSSION}

\section{Fidelity of Polar Bears to the Denning Area}

The 617 disturbance indicators on 72 trees collected at bear dens indicate that 12 of the 31 den sites were older than 100 years, and the oldest tree damage that we attributed to a polar bear occurred in 1795 . Our ability to confirm denning activity prior to 1795 was limited, as the age of the oldest stem we collected from a den site was only 236 years. Instability of older banks may have limited the ages of trees: as slumped dens eroded, trees may have fallen to the bottom of the bank and died. It is also possible that with years of abundant early snow, polar bears might have simply dug dens in drifted snowbanks, as they do elsewhere in the Arctic. However, in addition to being colder (Fayle et al., 1992), the period from approximately 1820 to 1880 was very dry, with little snow in central Canada by comparison to today (see Harington, 1992). As mentioned earlier, the snowfall statistics indicate that even in these relatively wet years, the autumn snowfall is deficient during most years. Thus, we suspect that further 


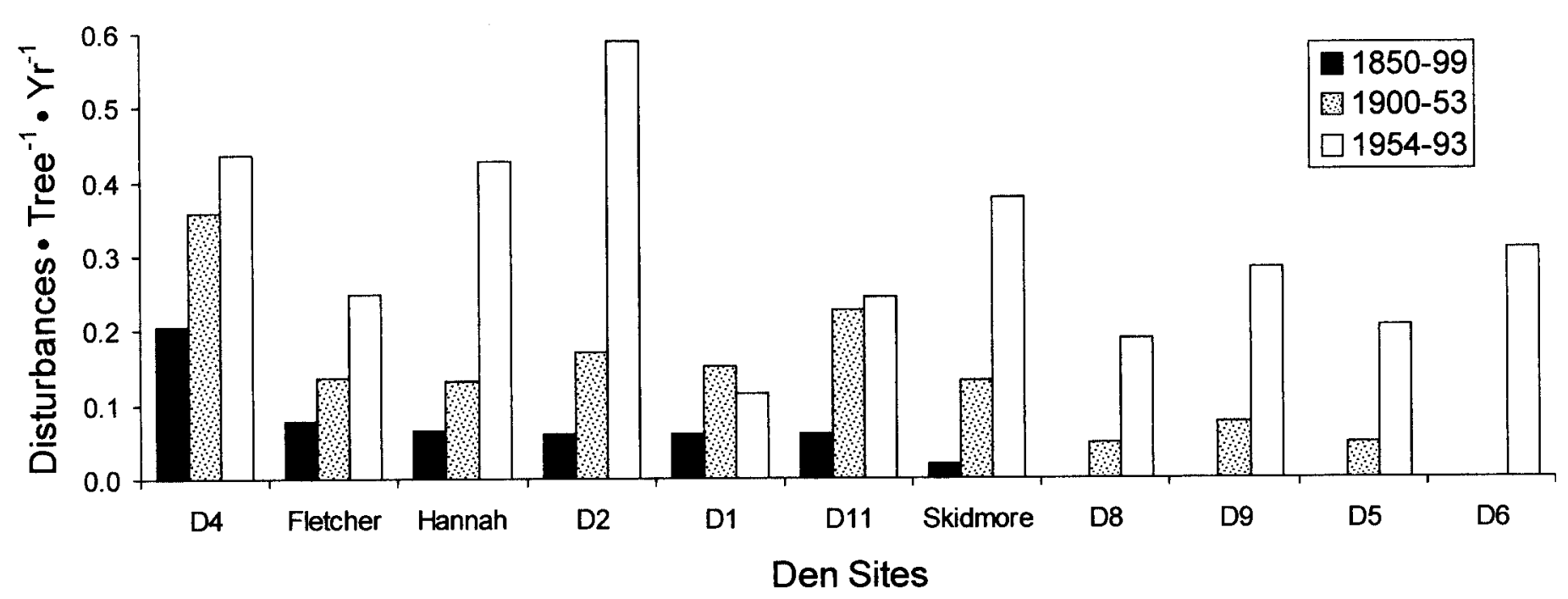

$1850-99$ to $1900-53$

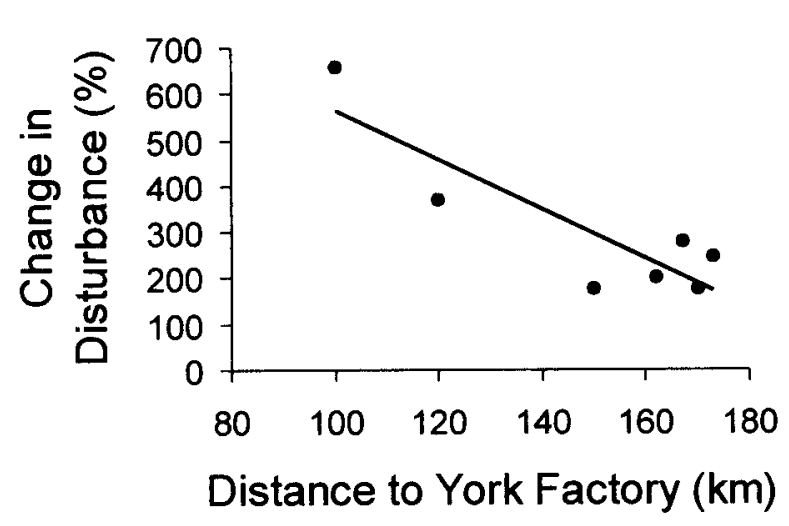

$1900-53$ to $1954-93$

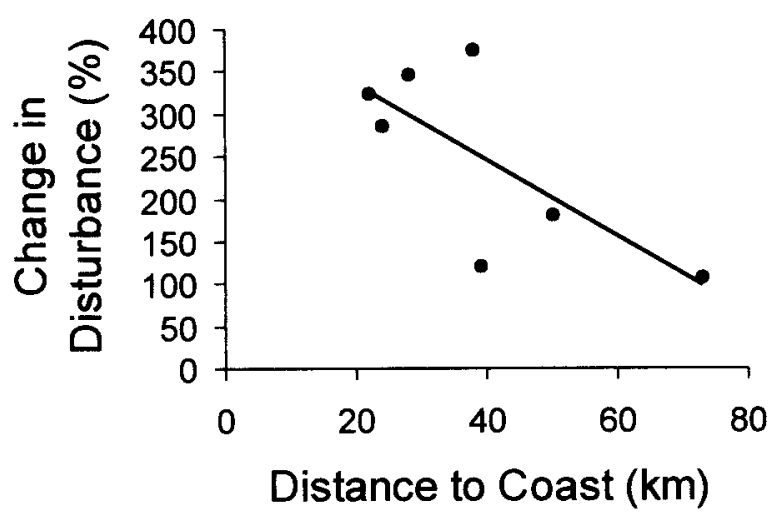

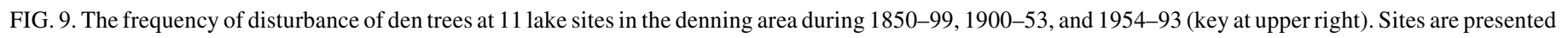

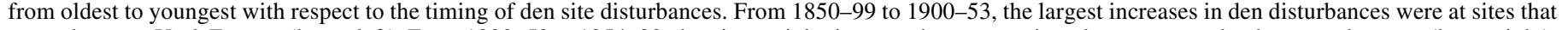

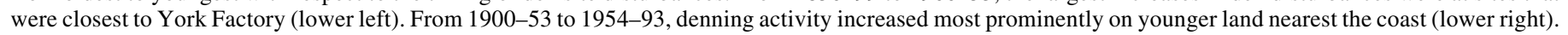
(Den site D12 has not existed for an entire period and therefore is not included.)

searching for older den sites will confirm a longer history of maternity denning in this area than we have been able to confirm to date.

Polar bears in western Hudson Bay are fairly consistent in their choice of den sites (Clark et al., 1997). Most dens or attempted dens are in peat banks beneath krummholz spruce and occasionally in peat banks without any trees, or in inorganic sediments along eroded river banks. Some are found in areas far outside what is traditionally known as the denning area. However, we estimate that more than $90 \%$ of the bears in this population den in this region: several thousand dens have already been excavated, making it the most concentrated denning area in Canada. In the 1980s, this population also had the highest natality rate recorded in Canada (Ramsay and Stirling, 1988). The continued selection of den sites in such a concentrated area and the repeated interest in recently used dens (Fig. 7) suggest that the den sites available there have qualities that contribute significantly to the breeding success of this population.

Initially, maternity denning in this western Hudson Bay area could have begun simply because it is adjacent to where the last ice on Hudson Bay melts in summer. The bears would therefore come ashore there to fast on their fat reserves until freeze-up in the fall (Stirling et al., 1977). Since female polar bears show fidelity to denning areas, they would probably have returned to the area to den again once successful. Movements of radio-collared bears show that even when they leave the ice in a different area of the coast, they return to the same denning area (Stirling et al., 1999; Stirling, unpubl. data). Further, the specific preferred habitat is concentrated on the west coast of Hudson Bay rather than widely dispersed at low densities, as it is in the High Arctic (e.g., Stirling et al., 1984).

All of the study dens had three characteristics that make the region unique. First, there was 150 to $300 \mathrm{~cm}$ of peat, which takes a considerable time to accumulate even in the absence of deep burning fires. By our calculations from the uplift curve established by Dredge et al. (1986), the dens found in the youngest land were dug in peat that had been accumulating for approximately $2000 \pm 100$ years. Second, as peat accumulates, permafrost aggrades from below, drawing water to the plane of freezing (Zoltai and 
Tarnocai, 1975; Seppala, 1995). The more water available, the greater the upward expansion when permafrost aggrades. In these riparian habitats, the upward heave of the land should be greater at the water's edge and less farther away. This process explains the large, dry, peat banks, which have a relatively large annual depth of thaw of approximately $60-120 \mathrm{~cm}$ beneath exposed surfaces (Beckel, 1957; Brown, 1978; Rouse, 1984; Clark and Stirling, 1997). A bear can dig an entrance in a peat bank up to $120 \mathrm{~cm}$ deep by digging through the active layer into the permafrost and then digging to the left or right to excavate the main body of the den (see Clark et al., 1997). The third characteristic is the dense, shrubby black spruce growth on the top of the peat banks (Jonkel et al., 1972; Clark et al., 1997) that occurs in the latest stages of bank development (Railton and Sparling, 1973; Camill, 1999). Dens dug in treeless sphagnum appear unstable, wet, and prone to collapse. In dens excavated beneath spruce growing along the top of a bank, the dense tree root matrix strengthens the bank, which delays its slumping into the water and keeps the den roof from collapsing (Clark et al., 1997). The tree crowns may also enhance snow accumulation below the banks. Finally, an extensive amount of this suitable habitat exists in a relatively localized area (Clark et al., 1997; Stirling et al., 1977). To the southeast of York factory on the Nelson River, comparable areas of suitable habitat are present, but they are small, localized, and surrounded by standing water. Because the permafrost is discontinuous and localized (Zoltai, 1969; Railton and Sparling, 1973; Thie, 1974), cryogenic features are much smaller, wetter, and prone to collapse during warm summers (Zoltai, 1971; Thie, 1974; Halsey et al., 1995; Camill, 1999). Krummholz spruce forms that weigh up to $3 \mathrm{~kg}$, about $80 \%$ of which is root biomass (e.g., Fayle and Scott, 1995), are common in the denning area (Ritchie, 1960, 1962). Farther south, however, these spruce are replaced by much larger and scattered tree and shrub forms. Larger trees are far more prone to wind stress, and digging around them may destabilize the ground. Consequently, the denning bears of southern Hudson Bay are dispersed over a much larger area at low density (Kolenosky and Prevett, 1983; Lunn et al., 1997). In regions north of the denning area, much less peat has accumulated and few trees are present to secure the banks (Dredge et al., 1986), so far fewer sites suitable for terrestrial denning exist. Furthermore, the sea ice does not normally break up north of Churchill, so bears are not normally found fasting there in late summer and fall. Possibly for these and other reasons, few maternity dens in earth have been reported north of the Churchill region (Stirling et al., 1977; Ramsay and Stirling, 1988; Clark et al., 1997; MacDonald et al., 1997).

Female bears that do not lose their cubs den at two- or three-year intervals (Ramsay and Stirling, 1988; Stirling et al., 1999). Therefore, we would not normally expect individual females to use the same den in subsequent years. However, den reuse, as indicated by den disturbances, revealed that despite a large choice of dens and locations to excavate a den, $57 \%$ of freshly used dens were disturbed again within two years. Yet all of these den sites were undisturbed for at least 10 years prior to first reuse. Furthermore, den sites nearest to York Factory, which had a low frequency of use early on, showed a high frequency of reuse in the post-hunting period. The threat of predation by adult males (Taylor et al., 1985; Derocher and Stirling, 1990) appears to explain, at least in part, the separation of females accompanied by cubs into the inland areas-away from the coast, where males are most abundant (Derocher and Stirling, 1990). During mark-recapture studies, we have seen individual dens used by different females in consecutive years and also noted females with cubs within a few kilometres of their old dens in subsequent years. We have not yet found a den being reused by the same female (Ramsay and Stirling, 1990; Stirling, unpubl. observations). Intra- and interspecific predation on female bears in maternity dens has been documented in other species of bears (e.g., Boyd and Heger, 2000), so it is possible that the threat of predation might also influence individual female polar bears to avoid the same den sites if the locations of their dens were predictable. In the post-hunting period, some individual den sites were apparently reused after an absence of as much as 29 years, and subsequent tree disturbance data indicate that several were then re-excavated and probably reused annually for 12 years or more. Dens may require re-excavation after being abandoned for a number of years because the permafrost melts around them as they age, causing collapse. Reusing a freshly dug den may thus be advantageous, as restoring it requires less energy than beginning a new den or renovating an old, collapsed site.

From the perspective of long-term conservation, the demonstrated fidelity of polar bears within a population to the same maternity denning area for at least 200 years (and likely much longer) is extremely important. It suggests that polar bears in more northerly areas show similar behaviour. However, because bears in most other populations den in snow, no records of their maternity dens remain after the snow melts. Knowledge of denning activity over periods of decades or longer is therefore limited to those locations people have visited in spring over a period of years and to adult females followed by satellite tracking for periods of five or more years (e.g., Amstrup and Gardner, 1994; Ferguson et al., 2000). Our data from western Hudson Bay clearly indicate that protecting core maternity denning areas is important to the long-term conservation of any polar bear population.

\section{Climate, Hunting, and Denning Area Disturbance Rates}

The temperature of the region has been recorded regularly since 1931, and the climate has been estimated through dendrochronology back to 1715 (Scott et al., 1988). During 1820-1920 the climate was very cool, which we know from modern analogue situations can be favourable for polar bears (Stirling et al., 1999). The 
warming that began in the 1880 s increased after 1920 and reached a peak in 1930-43. Subsequently there was a slight cooling through to the late 1970s, after which the weather records show a clear warming trend through to 1999 (Skinner et al., 1998). Overall, the 20th century was much warmer than the 19th. The three periods we selected correspond to unregulated hunting and cool climatic conditions (1850-99), partially regulated hunting coinciding with a gradual warming trend (1900-53), and prohibited hunting during a warm period, with a significant warming taking place after 1980 (1954-93). Overall, bear disturbance rates at the den sites increased from the 1920s until the late 1970s; since that time, they have fluctuated around a similar average level. In general, there does not appear to be a relationship between the climate trends and the rates of den disturbance during the overall 1850-1993 period. Although our samples are limited in number, size, and geographical distribution, we believe that changes in the frequency and pattern of disturbances at den sites may be related to the pattern of hunting and trading of hides at York Factory during the 19th and early 20th century.

Dens and denning activity in the Churchill region were first reported by Hearne (1795), and one of the first polar bear incidents recorded in this region, reported by Jens Munk, took place at Churchill in 1619 (Kenyon, 1980), so we suspect that polar bears were denning there before our earliest dates for disturbance. Active trading of polar bear hides began more than two centuries ago with the Cree and other residents around York Factory (Honderich, 1991). While Honderich (1991) gives a thorough coverage of where hunting occurred along the coast from the written record, most of the trading was done by representatives of a culture with an oral tradition. As a result, little is recorded about the sources of polar bear hides, except that elders in the region still remember hunting of female bears and cubs in the denning area in spring. York Factory traded the largest proportion of immature hides of any Hudson's Bay Company post, and during the 1900-20 harvest period, as many as 50 adult bear hides were traded annually (Honderich, 1991). At Skidmore Lake, the lake closest to York Factory, we did not detect any denning during the 1900-20 period, whereas the lake farthest from York Factory (Hannah) had the highest and most consistent level of denning activity. These data suggest that the active harvesting of polar bears by hunters at York Factory might be related to the low frequency of den disturbances. Both bears with fidelity to southern parts of the denning area and bears that left the ice south of the denning area would have had to travel into the region around York Factory, where they would have been more likely to be killed. As the trade in hides decreased in the 1920s and later, the frequency of den site use increased, especially at sites closest to York Factory.

Since the 1910s, the frequency of disturbances to spruce trees at the dens has shown a persistent increase, especially in areas at the periphery of the main den concentrations. This increase coincides with the time when the denning area was incorporated into the province of Manitoba (1912), increasingly more regulation was implemented, and correspondingly fewer hides were traded (Honderich, 1991). In 1946, polar bear hunting was banned for non-Native hunters, and in 1954 commercial hunting was banned altogether (Manitoba, 1954). Aboriginal activity around York Factory declined markedly after completion of the Hudson Bay Railroad in 1929 (Donaldson, 1981) and almost completely stopped after 1952-56, when York Factory was abandoned (Kidd, 1957). During the 1900s, the rate of disturbance at the dens in our sample increased fivefold, most noticeably in the southern areas adjacent to York Factory before 1954, and subsequently at younger lakes nearer to the coast. The steady increase in den disturbances corresponds closely to a decline in hunting, which likely indicates an increase in the population of polar bears in the denning area. Because movement from one location in the denning area to another would cause local declines, such a general increase in den disturbances makes it clear that mature bears had returned to old den sites initially. It is not clear whether, or where, those bears were denning before their return. Activation of sites on younger lakes near the coast in the later period may be related to the population increase that occurred through the 1970s, after which the population appeared to stabilize (Derocher and Stirling, 1995; Stirling et al., 1999).

In summary, the analysis of tree growth anomalies indicates that polar bears have denned in the study area for several hundred years. Following a period when bear activity was low, possibly because of human activity, bears returned to occupy those locations after the humans departed. When considered along with the fidelity to the denning area that polar bears have demonstrated over the last 30 years, these results indicate that female polar bears in the western Hudson Bay polar bear population have likely shown a steady degree of fidelity to this area for at least several hundred years. Protection of the preferred areas of maternity denning habitat (now largely contained within Wapusk National Park) will be beneficial to the survival of this population. Similarly, these results suggest that female polar bears in other areas of the Arctic probably show fidelity to specific areas for maternity denning and that such areas are likely also important to the conservation of the species.

\section{ACKNOWLEDGEMENTS}

Assistance in the field was provided by D.A. Andriashek, Wendy Calvert, D.A. Clark, D.C.F. Fayle, N.J. Lunn, S. Miller, and Cheryl Spencer. Logistical support was provided by the Churchill Northern Studies Centre and J. Miller. Tree-ring equipment was supplied by D.C.F. Fayle (Faculty of Forestry, University of Toronto) and I. Campbell (Northern Forestry Centre, Canadian Forestry Service). Programming was assisted by T. Smith, and densitometry was done by T. Varem-Sanders. B. Maxwell, Meteorological Service of Canada, supplied temperature and snow data, B. Mantha, S. Payette, and L. Filion provided additional material, and C. Elliott, 
Manitoba Department of Conservation, gave helpful information and advice. Funding from the Canadian Wildlife Service, Nunavut Wildlife Management Board, National Fish and Wildlife Foundation, Heritage Canada, the Natural Sciences and Engineering Research Council, and World Wildlife Fund (Canada) is gratefully acknowledged. Three reviewers provided comments that greatly improved the manuscript.

\section{REFERENCES}

AMSTRUP, S.C., and GARDNER, C. 1994. Polar bear denning in the Beaufort Sea. Journal of Wildlife Management 58:1-10.

BECKEL, D.K.B. 1957. Studies on seasonal changes in the active layer of soil at Fort Churchill, Manitoba. Arctic 10:151-183.

BÉGIN, Y., and PAYETTE, S. 1988. Dendroecological evidence of lake-level changes during the last three centuries in subarctic Québec. Quaternary Research 30:210-220.

- 1991. Population structure of lakeshore willows and icepush events in subarctic Québec, Canada. Holarctic Ecology 14:9-17.

BOYD, D.K., and HEGER, E.E. 2000. Predation of a denned black bear, Ursus americanus, by a grizzly bear, U. arctos. Canadian Field-Naturalist 114:507-508.

BROWN, R.J.E. 1978. Influence of climate and terrain on ground temperatures in the continuous permafrost zone of northern Manitoba and Keewatin District, Canada. In: Proceedings of the Third International Conference on Permafrost, I, 10-13 July 1978, Edmonton, Alberta. Ottawa: National Research Council of Canada. 15-21.

CAMILL, P. 1999. Peat accumulation and succession following permafrost thaw in the boreal peatlands of Manitoba, Canada. Ecoscience 6:592-602.

CLARK, D.A., and STIRLING, I. 1997. Habitat preferences of polar bears in the Hudson Bay Lowlands during late summer and fall. Ursus 10:243-250.

CLARK, D.A., STIRLING, I., and CALVERT, W. 1997. Distribution, characteristics, and use of earth dens and related excavations by polar bears on the western Hudson Bay Lowlands. Arctic 50:158-166.

CLOUTIER, J. 1995. Analyse dendroécologique d'une frange forestière soumise à l'etourbement sur une île centrale du lac Bienville, Québec subarctique. M.A. Thesis, Département de géographie Université Laval, Sainte-Foy, Québec.

COURNOYER, L., and FILION, L. 1994. Variation in wood anatomy of white spruce in response to dune activity. Arctic and Alpine Research 26:412-417.

DEROCHER, A.E., and STIRLING, I. 1990. Observations of aggregating behaviour in adult male polar bears (Ursus maritimus). Canadian Journal of Zoology 68:1390-1394.

- 1995. Estimation of polar bear population size and survival in western Hudson Bay. Journal of Wildlife Management 59: 215-221.

DEROCHER, A.E., STIRLING, I., and ANDRIASHEK, D. 1992. Pregnancy rates and serum progesterone levels of polar bears in western Hudson Bay. Canadian Journal of Zoology 70: $561-566$.
DIONNE, J.-C. 1979. Ice action in the lacustrine environment. A review with particular reference to subarctic Québec, Canada. Earth Science Review 15:185-212.

DONALDSON, B.F. 1981. York Factory: A land use history. Parks Canada Report No. 444. Ottawa.

DOUTT, J.K. 1967. Polar bear dens on the Twin Islands, James Bay, Canada. Journal of Mammalogy 48:468-471.

DREDGE, L.A., and NIXON, F.M. 1992. Glacial and environmental geology of northeastern Manitoba. Geological Survey of Canada Memoir 432. Ottawa.

DREDGE, L.A., NIXON, M., and RICHARDSON, R.J. 1986. Quaternary geology and geomorphology of northwestern Manitoba. Geological Survey of Canada Memoir 418. Ottawa.

FAYLE, D.C.F. 1968. Radial growth in tree roots. Technical Report No. 9. Toronto: University of Toronto, Faculty of Forestry.

FAYLE, D.C.F., and MacIVER, D.C. 1986. Growth layer analysis as a method of examining tree growth and development responses. In: Solomon, D.S., and Brann, T.B., eds. Environmental influences on tree and stand increment. Maine Experimental Station, University of Maine, Miscellaneous Publication 691. 40-48.

FAYLE, D.C.F., and SCOTT, P.A. 1995. Woody root system development of white spruce layerings in a tundra environment. Écoscience 2:408-414.

FAYLE, D.C.F., BENTLEY, C.V., and SCOTT, P.A. 1992. How did treeline white spruce at Churchill, Manitoba respond to conditions around 1816? In: Harington, C.R., ed. The year without a summer? World climate in 1816. Ottawa: Canadian Museum of Nature. 281-290.

FERGUSON, S.H., TAYLOR, M.K., ROSING-ASVID, A., BORN, E.W., and MESSIER, F. 2000. Relationship between denning of polar bears and conditions of sea ice. Journal of Mammalogy 81:1118-1127.

GLEUK, A.C. 1957. York Factory: The fading glory. Beaver 288:50-56.

HALSEY, L.A., VITT, D.H., and ZOLTAI, S.C. 1995. Disequilibrium response of permafrost in boreal continental western Canada to climate change. Climatic Change 30:57-73.

HARINGTON, C.R. 1968. Denning habits of the polar bear. Canadian Wildlife Service Report Series No. 5. Ottawa.

_ ed. 1992. The year without a summer? World climate in 1816. Ottawa: Canadian Museum of Nature.

HEARNE, S. 1795. A journey from Prince of Wales Fort in Hudson's Bay to the northern ocean in the years 1769, 1770, 1771, and 1772. Toronto: The Champlain Society (1911 edition).

HONDERICH, J.E. 1991. Wildlife as a hazardous resource: An analysis of the historical interaction of humans and polar bears in the Canadian Arctic 2,000 B.C. to A.D. 1935. M.A. Thesis, University of Waterloo, Waterloo, Ontario.

IUCN POLAR BEAR SPECIALIST GROUP. 1998. Status of the Polar Bear. In: Derocher, A.E., Garner, G.W., Lunn, N.J., and Wiig, Ø. eds. Polar Bears: Proceedings of the Twelfth Working Meeting of the IUCN/SSC Polar Bear Specialist Group, 3-7 February 1997, Oslo, Norway. Cambridge: IUCN Publications Unit. 23-44.

JIN-XING, L., and ZHENG-LI, L. 1993. Comparative observations of resin canals in secondary xylem of three species of normal and dwarf pines. Acta Botanica Sinica 35:362-366. 
JONKEL, C.J., KOLENOSKY, G.B., ROBERTSON, R.J., and RUSSELL, R.H. 1972. Further notes on polar bear denning habits. In: Herrero, S., ed. Bears: Their biology and management. Morges, Switzerland: IUCN. 142-158.

KEITH, L.B. 1963. Wildlife's ten year cycle. Madison: University of Wisconsin Press.

KENYON, W.A. 1980. The journal of Jens Munk 1619-1620. Toronto: Royal Ontario Museum.

KIDD, K. 1957. York Factory: Trading into Hudson's Bay. Beaver 288:12-17.

KOLENOSKY, G.B., and PREVETT, J.P. 1983. Productivity and maternity denning of polar bears in Ontario. International Conference on Bear Research and Management 5:238-245.

LARSEN, T. 1985. Polar bear denning and cub production in Svalbard, Norway. Journal of Wildlife Management 49: 320-326.

LENTFER, J.W. 1975. Polar bear denning on drifting sea ice. Journal of Mammalogy 56:716-718.

LEPAGE, H., and BÉGIN, Y. 1996. Tree-ring dating of extreme water level events at Lake Bienville, subarctic Québec, Canada. Arctic and Alpine Research 28:77-84.

LUNN, N.J., STIRLING, I., ANDRIASHEK, D., and KOLENOSKY, G.B. 1997. Re-estimating the size of the polar bear population in western Hudson Bay. Arctic 50: 234-240.

MacDONALD, M., ARRAGUTAINAQ, L., and NOVALINGA, Z., eds. 1997. Voices from the Bay: Traditional ecological knowledge of Inuit and Cree in the Hudson Bay Region. Ottawa: Canadian Arctic Resources Committee.

MANITOBA. 1954. A regulation governing the hunting and killing of polar or white bear made pursuant to "The Game and Fisheries Act." Manitoba Regulation 21/54. Winnipeg: Manitoba Gazette. 41.

METEOROLOGICAL SERVICE OF CANADA. 1995. Data from the Churchill Weather Office for snowfall and snow accumulation. Meteorological Service of Canada, 4905 Dufferin Street, Toronto, Ontario M3H 5T4, Canada.

MORNEAU, C., and PAYETTE, S. 1998. A dendroecological method to evaluate past caribou (Rangifer tarandus L.) activity. Écoscience 5:64-76.

PANSHIN, A.J., and DE ZEEUW, C. 1970. Textbook of wood technology (Vol. 1). Toronto: McGraw-Hill.

PAYETTE, S. 1987. Recent porcupine expansion at tree line: A dendroecological analysis. Canadian Journal of Zoology 65: $551-557$.

PAYETTE, S., and DELWAIDE, A. 1994. Growth of black spruce at its northern range limit in Arctic Quebec, Canada. Arctic and Alpine Research 26:174-179.

PAYETTE, S., DELWAIDE, A., MORNEAU, C., and LAVOIE, C. 1994. Stem analysis of a long-lived black spruce clone at treeline. Arctic and Alpine Research 26:56-59.

RAILTON, J.B., and SPARLING, J.H. 1973. Preliminary studies on the ecology of palsa mounds in northern Manitoba. Canadian Journal of Botany 51:1037-1044.

RAMSAY, M.A., and STIRLING, I. 1988. Reproductive biology and ecology of female polar bears (Ursus maritimus). Journal of Zoology (London) 214:601-634.
1990. Fidelity of female polar bears to winter-den sites. Journal of Mammalogy 71:233-236.

RITCHIE, J.C. 1960. The vegetation of northern Manitoba V. Establishing the major zonation. Arctic 13:211-229.

. 1962. A geobotanical survey of northern Manitoba. Technical Paper No. 9. Calgary, Alberta: Arctic Institute of North America.

ROUSE, W.R. 1984. Microclimate of the arctic treeline 2. Soil microclimate of tundra and forest. Water Resources Research 20:67-73.

SCOTT, P.A., BENTLEY, C.V., FAYLE, D.C.F., and HANSELL, R.I.C. 1987. Crown forms and shoot elongation of white spruce at the treeline, Churchill, Manitoba, Canada. Arctic and Alpine Research 19:175-186.

SCOTT, P.A., FAYLE, D.C.F., BENTLEY, C.V., and HANSELL, R.I.C. 1988. Large scale changes in atmospheric circulation interpreted from patterns of tree growth at Churchill, Manitoba, Canada. Arctic and Alpine Research 20:199-211.

SEPPALA, M. 1995. How to make a palsa: A field experiment on permafrost formation. Zeitschrift für Geomorphologie. N.F. 99:91-96.

SINCLAIR, A.R.E., GOSLINE, J.M., HOLDSWORTH, G., KREBS, C.J., BOUTIN, S., SMITH, J.N.M., BOONSTRA, R., and DALE, M. 1993. Can the solar cycle and climate synchronize the snowshoe hare cycle in Canada? Evidence from tree rings and ice cores. American Naturalist 141:173-198.

SKINNER, W.R., JEFFERIES, R.L., CARLETON, T.J., ROCKWELL, R.F., and ABRAHAM, K.F. 1998. Prediction of reproductive success and failure in lesser snow geese based on early season climatic variables. Global Change Biology 4:3-16.

SOKAL, R.R., and ROHLF, F.J. 1995. Biometry. 3rd ed. New York: W. H. Freeman.

STIRLING, I., and ANDRIASHEK, D. 1992. Terrestrial maternity denning of polar bears in the eastern Beaufort Sea area. Arctic 45:363-366.

STIRLING, I., JONKEL, C., SMITH, P., ROBERTSON, R., and CROSS, D. 1977. The ecology of the polar bear (Ursus maritimus) along the western coast of Hudson Bay. Canadian Wildlife Service Occasional Paper No. 33. Ottawa.

STIRLING, I., CALVERT, W., and ANDRIASHEK, D. 1984. Polar bear ecology and environmental considerations in the Canadian High Arctic. In: Olson, R., Hastings, R., and Geddes, F., eds. Northern ecology and resource management. Edmonton: University of Alberta Press. 201-222.

STIRLING, I., LUNN, N.J., and IACOZZA, J. 1999. Long-term trends in the population ecology of polar bears in western Hudson Bay in relation to climate change. Arctic 52:294-306.

STOCKTON, C.W., and FRITTS, H.C. 1973. Long-term reconstruction of water level changes for Lake Athabasca by analysis of tree rings. Water Resources Bulletin 9:10061027.

TAYLOR, M., LARSEN, T., and SCHWEINSBURG, R.E. 1985. Observations of intraspecific aggression and cannibalism in polar bears (Ursus maritimus). Arctic 38:303-309.

THIE, J. 1974. Distribution and thawing of permafrost in the southern part of the discontinuous zone in Manitoba. Arctic 27:189-200. 
USPENSKI, S.M., and KISTCHINSKI, A.A. 1972. New data on winter ecology of the polar bear (Ursus maritimus Phipps) on Wrangel Island. International Conference on Bear Research and Management 2:181-197.

VAREM-SANDERS, T.M.L., and CAMPBELL, I.D. 1996. DENDROSCAN: Tree-ring width and density measurement. Canadian Forestry Service Special Report 10. Ottawa.

WARDROP, A.B. 1964. The nature of reaction wood. In: Zimmerman, M.H., ed. The formation of wood in forest trees. New York: Academic Press. 405-456.
ZOLTAI, S.C. 1969. Permafrost in peat landforms in northern Manitoba. In: Proceedings of the Thirteenth Annual Manitoba Soil Science Meeting. Winnipeg, Manitoba: University of Manitoba. 3-16.

. 1971. Southern limit of permafrost features in peat landforms, Manitoba and Saskatchewan. Geological Association of Canada Special Paper No. 9. Ottawa.

ZOLTAI, S.C., and TARNOCAI, C. 1975. Perennially frozen peatlands in the western Arctic and Subarctic of Canada. Canadian Journal of Earth Science 12:28-43. 